\title{
Florence Harriman i jej praca dyplomatyczna w Norwegii, 1937-1940*
}

\begin{abstract}
Abstrakt: Celem niniejszego artykułu jest przybliżenie pracy dyplomatycznej Florence Harriman (1870-1964), powołanej przez prezydenta Franklina D. Roosevelta w 1937 r. na stanowisko posła Stanów Zjednoczonych w Norwegii. W uznaniu jej wieloletniej aktywności publicznej, zwłaszcza w klubach kobiecych Partii Demokratycznej, i dzięki zabiegom aktywistek z kręgów Eleanor Roosevelt powierzono jej, jako drugiej Amerykance w historii dyplomacji, kierowanie placówką w Oslo w latach 1937-1940.
\end{abstract}

Słowa kluczowe: Florence Jaffray Harriman, Franklin D. Roosevelt, Eleanor Roosevelt, dyplomacja USA, Norwegia, kobiety.

Abstract: The purpose of the present article is to shed light on diplomatic work of Florence Harriman (1870-1964), appointed by President Franklin D. Roosevelt as the United States' minister to Norway in 1937. In recognition of her long and distinguished public service, especially in women's clubs of the Democratic Party, and thanks to efforts of female activists from Eleanor Roosevelt's circles - she was placed, as the second American woman in the history of diplomacy, at the head of a diplomatic mission in Oslo in 1937-1940.

Key w or d s: Florence Jaffray Harriman, Franklin D. Roosevelt, Eleanor Roosevelt, US Diplomacy, Norway, women.

W kampanii prezydenckiej 1932 r. Franklin D. Roosevelt otwarcie zabiegał o poparcie kobiet i zapowiadał też new deal for the forgotten woman. Znaczne poparcie kobiecego elektoratu zawdzięczał w dużej mierze Eleanor Roosevelt

* Przygotowanie artykułu było możliwe dzięki stypendium Roosevelt Institute on American Studies (RIAS) w Middelburgu i przeprowadzeniu tam kwerendy archiwalnej. 
i Mary (Molly) Dewson, szefowej Women's Division of the Democratic National Committee. I tej ostatniej, przy konsekwentnym poparciu małżonki prezydenta, przypisuje się faktyczne wypromowanie Frances Perkins - pierwszej kobiety na stanowisko ministerialne. Jej nazwisko pojawiało się nieraz $\mathrm{w}$ mediach, a kobiety coraz częściej pisały $\mathrm{w}$ tej sprawie petycje do Roosevelta, m.in. zasłużona i powszechnie szanowana Jane Addams ${ }^{1}$.

Mimo niekwestionowanego profesjonalizmu Perkins, jej dobrego przygotowania i doświadczenia $\mathrm{w}$ działalności publicznej, sam prezydent $\mathrm{w}$ kręgu zaufanych wyrażał obawy, że powierzenie jej stanowiska ministra pracy będzie precedensem trudnym do zaakceptowania przez wielu polityków. Roosevelt obawiał się, że mężczyźni z kręgów rządowych tego nie zaaprobuja, a w samym ministerstwie też pojawią się trudności z akceptacją podległości jej męskich pracowników. Decyzję wszak ostatecznie podjął pod niemałym wpływem małżonki, choć ona sama publicznie podkreślała, że była to samodzielna decyzja prezydenta, który po prostu, niezależnie od płci, doceniał zaangażowanie i profesjonalizm swoich współpracowników². Warto dodać, że powierzenie stanowiska Perkins, jak się miało okazać, było dobrą decyzja. Urząd swój sprawowała przez wiele trudnych lat w czasie wielkiego kryzysu gospodarczego i II wojny światowej, zasłużenie przechodząc do historii jako jedna z najlepszych ministrów pracy. Stała się dla Amerykanek przykładem kobiecego sukcesu.

Franklin D. Roosevelt już na początku swego urzędowania powołał tė̇ kilka innych kobiet na ważne stanowiska. Nellie Tayloe Ross, byłej gubernator Wyoming, powierzył kierowanie Mennicą Państwową USA. Z kolei Florence Allen jako pierwsza kobieta objęła prestiżowy urząd w Okręgowym Sądzie Apelacyjnym (Circuit Court of Appeals), a kilkadziesiąt innych Amerykanek otrzymało oferty pracy na ważnych stanowiskach w kilku ministerstwach. Nominacje te były swego rodzaju precedensem, na które bodaj największy wpływ miała grupa, tzw. women folk, skupiona wokół Eleanor Roosevelt, usilnie zabiegajacca o powoływanie rodaczek na prestiżowe stanowiska. W mediach od początku prezydentury Roosevelta pisano o „kobiecym New Dealu”, wskazując na niezwykle aktywną i ważną rolę prezydentowej ${ }^{3}$, która z biegiem lat swoja pozycję ugruntowała. Do dziś w badaniach opinii publicznej Eleanor Roosevelt zajmuje wciąż niekwestionowane pierwsze miejsce jako najbardziej

${ }^{1}$ G. Martin, Madam Secretary. Frances Perkins, New York 1976, s. 235-238; L. Holmen Mohr, Frances Perkins. „That Woman in FDR's Cabinet”, Great Barrington 1979, s. 106-107; F. Perkins, The Roosevelt I Knew, London 1947, s. 98-110.

${ }^{2}$ L. Holmen Mohr, op. cit., 115-118; K. Downey, The Women Behind New Deal. The Life of Frances Perkins, FDR's Secretary of Labor and His Moral Conscience, New York 2009, s. $1-3,115-117$.

${ }^{3}$ Mr. Roosevelt's New Deal for women, http://www.unz.org/Pub/LiteraryDigest-1933apr15-00022 (dostęp: 15 VIII 2018); S.M. Evans, Born for Liberty. A History of Women in America, New York 1989, s. 204-207. 
zaangażowana, aktywna i podziwiana first lady4. I choć ona sama nie eksponowała swojej roli i zasług, ale konsekwentnie promowała kobiety, także w słynnej i poczytnej rubryce „My Day”. Z nieukrywaną satysfakcją mówiła o Amerykankach zajmujących coraz to ważniejsze stanowiska. Z dumą i uznaniem wypowiadała się na temat ich wzrastającej pozycji w życiu publicznym w kraju w latach trzydziestych XX w. Niezwykle popularna i wpływowa first lady pisała o zmianach nastawienia rodaków i samych kobiet do aktywności publicznej, a także politycznej. Wskazywała na powolna ewolucję stanowiska Amerykanów i nieunikniony proces wymuszający dalsze zmiany w tym względzie. Jak zauważyła, Amerykanki lepiej organizowały się i nabierały pewności siebie oraz przeświadczenia o swojej wartości, wkraczając coraz śmielej na ważne pola aktywności publicznej, także politycznej ${ }^{5}$.

Franklin D. Roosevelt był pierwszym prezydentem, który powołał dwie Amerykanki do kierowania poselstwami USA. Pierwsza z nich, Ruth Bryan Owen, córka znanego polityka, dziennikarka, działaczka klubów demokratycznych z doświadczeniem pracy w Kongresie jako reprezentantka Florydy, została wysłana do Kopenhagi w 1933 r. Była to nominacja typowo polityczna, w gruncie rzeczy za pomoc w kampanii wyborczej 1932 r. Jej kilkuletnia błyskotliwa kariera dyplomatyczna została przerwana z powodów osobistych, bowiem latem 1936 r. wyszła za mąż za Duńczyka, kapitana gwardii królewskiej ${ }^{6}$.

Druga Amerykanka, samodzielnie kierująca placówką zagraniczną USA, to Florence Jaffray Harriman wysłana przez Roosevelta do Oslo w 1937 r. (o czym za chwilę). Fakt, że były to pierwsze Amerykanki w randze posłów, postrzegano wówczas - jak pisały nieraz media - jako novelty, ale też jako gest wobec kobiet i ich aspiracji oraz wyraz uznania nie tylko czy nie tyle dla konkretnych osób, co w ogóle aktywistek w Partii Demokratycznej, konsekwentnie zabiegających o wprowadzenie kobiet na ważne stanowiska w administracji Roosevelta ${ }^{7}$.

Warto zauważyć, że pierwsze amerykańskie dyplomatki akredytowane były w państwach skandynawskich, podobnie jak Aleksandra Kołłątaj, radziecka ambasador w Norwegii (1923-1926 i 1927-1930), a potem w Szwecji

${ }^{4}$ Zob. H. Parafianowicz, Eleanor Anna Roosevelt. W cieniu wielkiego męża, Warszawa 2000.

${ }^{5}$ E. Roosevelt, Women in Politics, „Good Housekeeping”, I-IV 1940, nr 110, w: What I Hope to Leave Behind. The Essential Essays of Eleanor Roosevelt, red. A.M. Black, New York 1995, s. 252-256. W 1933 r. ok. 35 kobiet zajmowało prestiżowe i ważne funkcje rządowe, a w kolejnych latach ich liczba sukcesywnie wzrastała - do 55 w 1939 r.

${ }_{6}$ Zob. H. Parafianowicz, O pionierkach $w$ dyplomacji amerykańskiej i Ruth Bryan Owenpierwszej Madame Poset USA, „Dzieje Najnowsze” 2018, nr 3.

${ }^{7}$ L.W. Banner, Women in Modern America. A Brief History, New York 1973, s. 178-182; R. Jeffreys-Jones, Changing Differences. Women and the Shaping of American Foreign Policy, 1917-1994, New Brunswick 1995, s. 75; S. Ware, Beyond Suffrage. Women in the New Deal, Cambridge 1981, s. 147. 
$(1930-1945)^{8}$. Być może miało to pewien związek z faktem otrzymania przez kobiety w tych krajach, wcześniej niż gdzie indziej, praw wyborczych. Norwegia już w 1913 r. przyznała kobietom prawa wyborcze, tym samym stając się jednym z pierwszych państw - obok Finlandii i Danii - które uczyniły to kilka lat wcześniej. Tak czy inaczej, Owen i Harriman zapoczątkowały swego rodzaju tradycję wysyłania Amerykanek na placówki do Skandynawii, gdyż po II wojnie światowej powierzano im nieraz kierowanie ambasadami USA w Oslo i Kopenhadze 9 .

Przyszła pani poseł w Oslo, Florence Jaffray Hurst urodziła się w 1870 r. w zamożnej rodzinie nowojorskiej. W 1889 r. wyszła za mąż za bankiera Jeffersona Borden Harrimana, prowadząc od początku dostatnie życie młodej matrony udzielającej się w pracach charytatywnych miejscowej socjety. Założyła w Nowym Jorku pierwszy klub kobiecy - Colony Club, któremu przewodniczyła w latach 1903-1916, stając się z czasem aktywną reformatorka, działaczka klubów kobiecych Partii Demokratycznej i zaangażowana sufrażystka. Od 1912 r. była przewodnicząca Federal Industrial Relations Commission, angażując się w poparcie Woodrow Wilsona i progresywne reformy jego administracji. Po śmierci męża w 1914 r. Florence Borden Harriman przeprowadziła się do Waszyngtonu, gdzie zaczęła systematycznie budować sieć swoich kontaktów towarzyskich i politycznych. W sierpniu 1914 r. współpracowała z Lou Henry Hoover w udzielaniu pomocy i organizowaniu powrotu Amerykanów, których wojna zaskoczyła w Europie. Po przystapieniu USA do I wojny światowej wspierała wysiłek wojenny rodaczek, propagujacc ich pracę w Amerykańskim Czerwonym Krzyżu (ACK), a zwłaszcza w kobiecych korpusach zmotoryzowanych ${ }^{10}$.

Od 1918 r. Florence Borden Harriman przebywała we Francji, a także w Wielkiej Brytanii, pracując w ACK. Szczególnie interesowała się sprawami międzynarodowymi i przygotowaniami przyszłej konferencji pokojowej oraz planami powołania Ligi Narodów, której była gorącą rzeczniczka. W Paryżu utrzymywała ożywione kontakty, spotykając się z wieloma osobistościami politycznymi, zarówno amerykańskimi (m.in. z prezydentem Wilsonem i jego małżonką Edith Bolling Galt Wilson oraz płk. Edwardem M. House’em), jak

${ }^{8}$ H. Wright, Can a Women Be a Diplomat?, „The North American Review”, Autumn 1939, s. 100-108, http://www.unz.com/print/NorthAmericanRev-1939q3-00100 (dostęp: 12 VI 2018).

9 A. Miller Morin, Her Excellency. An Oral History of American Women Ambassadors, New York 1995, s. 58, 277. Kolejną Amerykanką w Norwegii, już w randze ambasadora, była pierwsza tam profesjonalistka - Frances E. Willis (1957-1961), a potem Margaret Tibbetts (1964-1969). Do dziś 5 Amerykanek kierowało placówką dyplomatyczną USA w Oslo. Poczynając od Ruth Bryan Owen, Amerykanki były wysyłane również do kierowania placówką w Kopenhadze (zawsze z nominacji politycznej). Jako piąta w tym gronie znalazła się Carla Sands, nominowana przez prezydenta Donalda Trumpa i zatwierdzona przez Senat 2 XI $2017 \mathrm{r}$.

${ }^{10}$ Zob. https://www.britannica.com/biography/Florence-Jaffray-Harriman (dostęp: 15 VIII 2018); F. Harriman, From Pinafores to Politics, New York 1923, s. 162-186, 220, 273 i n. 
i politykami europejskimi, zwłaszcza brytyjskimi i francuskimi. Uczestniczyła w wydarzeniu historycznym, a mianowicie podpisaniu traktatu wersalskiego, o czym wspominała z satysfakcją i duma ${ }^{11}$. Liczne kontakty nawiązane w tym czasie z politykami i dyplomatami, także cudzoziemskimi, okażą się potem bardzo przydatne w późniejszej karierze.

Od początku lat dwudziestych XX w., także po śmierci Wilsona (3 II 1924), Florence Borden Harriman propagowała jego wizje polityczne, uczestnictwo Stanów Zjednoczonych w Lidze Narodów i ich udział w inicjatywach pokojowych. Współpracowała z Eleanor Roosevelt i nowojorskimi działaczkami w tworzeniu sieci klubów demokratek oraz aktywizacji elektoratu kobiecego w kolejnych wyborach. W latach 1922-1930 była przewodniczącą ogólnokrajowego Democratic Women's Club, wzmacniając swoją pozycję w kręgach politycznych $^{12}$.

„Daisy”, jak ją powszechnie nazywano w kręgu przyjaciół, pielęgnowała i wciąż budowała sieć kontaktów w waszyngtońskiej elicie, ciesząc się jej dużą popularnościa. Podtrzymywała liczne znajomości z lat współpracy $\mathrm{w}$ administracji Wilsona, m.in. z Williamem Phillipsem i płk. House’em. Miała też dobre kontakty i poparcie wielu osób wpływowych i polityków, m.in. Williama Forbesa Morgana, sen. Josepha T. Robinsona i innych. Była organizatorka popularnych przyjęć w jej słynnym potem domu w Uplands, który w latach republikańskich rządów stanowił „bastion” demokratów spotykających się tam i dyskutujących o ówczesnych sprawach krajowych oraz międzynarodowych i planujących powrót swego prezydenta do Białego Domu.

W kampanii prezydenckiej w 1932 r. Harriman początkowo poparła Newtona D. Bakera, bliskiego współpracownika Wilsona i ministra wojny w jego rządzie. Zaangażowanie w lansowaniu jego kandydatury wyhamowało czy też „zamroziło” w znacznym stopniu karierę polityczną Harriman po zwycięstwie Franklina D. Roosevelta, choć ten fakt dyskretnie przemilczała $\mathrm{w}$ pamiętnikach. W kolejnych latach, mimo jej powiązań z wieloma osobami z ówczesnej administracji, znalazła się jednak na „bocznym torze”. Jak potem twierdziła, początkowo była bardziej obserwatorką reform Roosevelta niż uczestniczką tych wielkich przedsięwzięć i przeobrażeń Ameryki. Ale blisko współpracowała m.in. z zaprzyjaźnioną z nią od lat Frances Perkins oraz Eleanor Roosevelt, co ją z czasem zbliżyło do kręgów zwolenników prezydenta i New Deal ${ }^{13}$. Kontakty te i współpraca z organizacjami kobiecymi uświadomiły jej w pełni, że polityka była i pozostała obiektem i centrum

${ }^{11}$ F. Harriman, op. cit., s. 220, 273 i n.

${ }_{12}$ M. Folly, N. Palmer, Historical Dictionary of U.S. Diplomacy from World War I through World War II, Lanham 2010, s. 145-146; D. Weatherford, American Women during World War II. An Encyclopedia, New York-London 2010, s. 199.

${ }^{13}$ L. Cores, Persons to Persons. Madame Minister, s. 446, http://www.unz.org/Pub/LivingAge-1940jan-00444 (dostęp: 15 VIII 2018); F. Jaffray Harriman, Mission to the North, Philadelphia-New York 1941, s. 26-28. 
jej zainteresowań oraz aktywności. W rezultacie więc zaangażowała się w kampanię prezydencką w 1936 r., wygłaszając - a była świetna mówczynia - liczne odczyty i wspierając tym razem wydatnie Roosevelta. Napisała potem krótko: „cieszyłam się każdą chwilą tej kampanii”, która przyniosła ogromny sukces Roosevelta ${ }^{14}$.

Marzenia Florence Harriman o pracy na ważnym stanowisku rządowym zdawały się coraz bliższe spełnienia po zwycięstwie Roosevelta w 1936 r., po którym powróciła do jego łask. Ten bezprecedensowy sukces prezydenta i okazane w wyborach ogromne poparcie rodaków dla programu reform ugruntowały na dobre jego pozycję i demokratów na amerykańskiej scenie politycznej. Wzrosła też rola i wpływy niezwykle aktywnej na wielu polach i bardzo popularnej first lady. Tajemnica poliszynela był fakt, że grupa aktywistek skupionych wokół Eleanor Roosevelt coraz skuteczniej zabiegała o udział kobiet w krajowej polityce i powierzanie im ważnych funkcji ${ }^{15}$. Kandydatura Harriman gościła coraz częściej na „giełdzie politycznej” osób planowanych do obejmowania ważnych stanowisk w państwie. Pojawiły się pogłoski, także pierwsze wzmianki prasowe, że być może zostanie wysłana na któraś z placówek zagranicznych USA ${ }^{16}$.

Wydawało się, na co zwracali uwagę przyjaciele Florence Harriman, że takim miejscem mogła być Kopenhaga po odejściu stamtąd Ruth Bryan Owen. Chyba nawet sondowano taka możliwość, ale - po wyjściu Owen za mąż za Duńczyka i jej rezygnacji ze służby zagranicznej - ponoć Dania nie akceptowała kolejnej Amerykanki na stanowisku posła w ich kraju. Złośliwi wprost twierdzili, że Duńczykom wystarczyła jedna amerykańska dyplomatka $\mathrm{z}$ „romantyczna historia miłosną" $\mathrm{z}$ ich obywatelem. Być może, bo i o tym spekulowano, chciano uniknąć niezręczności protokolarnych, także ze względu na ceremoniał królewski ${ }^{17}$.

Warto przypomnieć, że zgodnie z utrwalona tradycja tzw. łupów politycznych (spoils system) po zwycięskich wyborach nowa ekipa dokonywała też zmian w obsadzie wielu placówek zagranicznych USA. W ramach tych poczynań przeprowadzano przetasowania kadrowe oraz wymianę na wielu stanowiskach, powołując też zupełnie nowe osoby do pracy w dyplomacji. I tak ówczesny poseł w Norwegii, Anthony Drexel Biddle został - w ramach merytorycznych promocji - awansowany na stanowisko ambasadora i wysłany do Warszawy ${ }^{18}$. Na jego zaś miejsce rozważano kandydaturę Florence Harriman,

${ }^{14}$ F. Jaffray Harriman, op. cit., s. 34-36.

15 S. Ware, op. cit., s. 11. Do ścisłego kręgu Eleanor Roosevelt w latach trzydziestych XX w. badaczka zaliczyła 28 kobiet.

${ }^{16}$ F. Jaffray Harriman, op. cit., s. 36.

${ }^{17}$ L. Cores, op. cit., s. 446-447.

${ }^{18}$ Roosevelt Institute on American Studies (dalej: RIAS), President Franklin D. Roosevelt's Office Files, 1933-1945. Part 2: Diplomatic Correspondence File, Reel 2, Anthony J.D. Biddle Jr., 1937-1941. Raporty Biddle’a do prezydenta Roosevelta z 18 V i 20 V 1937 r. 
która czuła się zaszczycona taka propozycją prezydenta, choć zdawała sobie sprawę z wyzwań, które ją czekały. Ponoć miała nawet pewne wątpliwości, czy była to dobra decyzja, by wyjeżdżać tak daleko z kraju, zwłaszcza ze względu na wiek (miała wówczas blisko 67 lat). Ale jakoby córka bardzo ją do tego namawiała i przekonała, że będzie to dla niej „zupełnie nowe doświadczenie i prawdziwa przygoda"19. Nie do końca wiadomo, czym spowodowana też była pewna opieszałość Norwegów w akceptacji jej kandydatury, którzy po blisko 5 tygodniach udzielili agrément ${ }^{20}$.

$4 \mathrm{~V} 1937$ r. Senat zatwierdził kandydaturę Florence Harriman na stanowisko posła w Norwegii. Ona sama zaś już od tygodni starannie przygotowywała się do czekających ją zadań. Zasięgała praktycznych porad u przyjaciół, a zwłaszcza profesjonalistów, m.in. podsekretarza stanu Sumnera Wellesa oraz zaprzyjaźnionego z prezydentem, wpływowego i doświadczonego ambasadora we Francji, Williama C. Bullitta. Udawała się do przyjaznego kraju i na placówkę, jak o niej mówiono, „spokojną i dobrze prowadzoną” przez Anthony'ego Drexel Biddle'a. Ten zapalony narciarz i profesjonalny dyplomata w trakcie osiemnastomiesięcznego pobytu na placówce w Oslo zbudował sieć przyjaznych kontaktów w Norwegii, gdzie był bardzo lubiany i niezwykle popularny ${ }^{21}$. Harriman nawiązała z nim i jego żona Margaret serdeczny kontakt. Ceniła jego doświadczenie dyplomatyczne i fachowość. Korzystała też z praktycznych porad obojga i wskazówek przy organizacji pracy poselstwa. Otrzymała od nich listę kontaktów w Oslo, bardzo przydatnych do jej codziennej pracy i planowanych oficjalnych uroczystości. Niezwykle ciepło i z uznaniem napisała potem o profesjonalizmie i zasługach swego poprzednika dla rozwoju stosunków amerykańsko-norweskich ${ }^{22}$.

Na początku maja $1937 \mathrm{r}$. prezydent, jak to miał w zwyczaju, przyją nowa poseł na audiencji i udzielił jej - jak zapamiętała - życzliwych i niezwykle pożytecznych rad przed wyjazdem na placówkę do Oslo. Rozmowę i lunch w Białym Domu wspominała bardzo sympatycznie, tym bardziej że udzielone

${ }^{19}$ F. Jaffray Harriman, op. cit., s. 37.

${ }^{20}$ Notable American Women. The Modern Period. A Biographical Dictionary, red. B. Sicherman, C. Hurd Green, t. IV, Cambridge 1980, s. 315; L. Cores, op. cit., s. 447; „To Oslo”, 12 IV 1937 r. „Time” poinformował, że posłem w Norwegii będzie Florence Harriman. Zob. http://content.time.com/time/magazine/article/0,9171,788005,00.html (dostęp: 10 VIII 2018).

${ }^{21}$ RIAS, President Franklin D. Roosevelt's Office Files, 1933-1945. Part 2: Diplomatic Correspondence File, Reel 25, Norway, VII 1935 - XII 1935. Raporty Biddle'a do prezydenta, w których informował o swojej akredytacji, nawiązywanych kontaktach i licznych rozmowach z politykami norweskimi. Poseł żywo interesował się procedura przyznawania Pokojowej Nagrody Nobla, co może świadczyć, że już wtedy sondował szanse dla amerykańskiego kandydata. W.S. Cole, Norway and the United States, 1905-1955. Two Democracies in Peace and War, Ames 1989, s. 50-53. Warto dodać, że podczas II wojny światowej Biddle był akredytowany jako ambasador USA przy rządzie emigracyjnym Norwegii w Londynie, jak również przy kilku innych rządach na uchodźstwie, w tym także Polski.

${ }^{22}$ F. Jafrray Harriman, op. cit., s. 52-53. 
instrukcje Roosevelta miały się niebawem przydać. Zgodnie z jego sugestia zatrzymała się na kilka dni w Paryżu, a potem w Londynie, by lepiej zapoznać się z ówczesną sytuacją polityczną w Europie. Odwiedzając amerykańskie ambasady, spotykała się z ich pracownikami, jak też innymi Amerykanami oraz miejscowymi politykami i mediami ${ }^{23}$.

Zabawnie potem napisała, że ambasador Bullitt w trakcie spotkań i uroczystości oficjalnych w Paryżu przedstawiał ją niezwykle głośno i donośnie, podkreślając, że jest ona „amerykańskim posłem we własnej osobie, nie żoną posła” ${ }^{24}$. Jak widać, fakt, że kobieta miała kierować placówką dyplomatyczną USA, był wciąż czymś zaskakująco nowym i rzadko spotykanym również na salonach dyplomatycznych w Europie. Ona zaś odczuwała zarówno radość i dumę, jak i brzemię odpowiedzialności, że każdy jej gest czy potknięcie będzie wykorzystane jako argument przeciwników wysyłania kobiet do pracy dyplomatycznej.

W trakcie pobytu i podczas oficjalnych spotkań w Paryżu oraz Londynie Florence Harriman zaktualizowała informacje na temat sytuacji gospodarczo-politycznej w Europie. Wzbogaciła również wiedzę o arkanach dyplomacji, jak też czekających ją zadaniach. Nawiązała i odnowiła znajomości w kręgach dyplomatycznych, a także kontakty z amerykańskimi dziennikarzami akredytowanymi w stolicach europejskich, co już niebawem okazało się bardzo przydatne w jej pracy. Harriman w związku z czekajacymi ją licznymi obowiązkami ceremonialnymi - jak przystało na kobietę elegancką bywająca na salonach - poczyniła stosowne zakupy w Paryżu i Londynie. Starannie uzupełniła swoja garderobę, konsultując z doświadczonymi dyplomatami sprawy ceremoniału i etykiety obowiąującej na dworze królewskim w Oslo ${ }^{25}$. Czekające ją obowiązki dyplomatyczne traktowała bardzo poważnie. Miała też pełną świadomość, że jej praca będzie uważnie śledzona zarówno przez jej zwierzchników w Departamencie Stanu i w ogóle Amerykanów, a zwłaszcza rodaczki, jak i Norwegów. Tym bardziej starała się dobrze przygotować do czekającej ją misji dyplomatycznej, wyrażając nieraz przekonanie, że musi podołać tym oczekiwaniom i nie może nikogo zawieść.

Pod koniec czerwca 1937 r. Harriman opuściła Londyn, udając się statkiem do Bergen, gdzie powitali ja amerykański konsul i przedstawiciele rządu norweskiego, jak również dziennikarze, z którymi nawiązała od początku życzliwy kontakt, ułatwiony z powodu znajomości większości z nich języka angielskiego. Sekretarz amerykańskiego poselstwa w Oslo Jefferson Patterson $^{26}$ i cały personel przyjęli ją również serdecznie. 1 VII 1937 r. Florence

23 Ibidem, s. 38-45.

${ }^{24}$ Ibidem, s. 43.

${ }^{25}$ RIAS, President Franklin D. Roosevelt's Office Files, 1933-1945. Part 2: Diplomatic Correspondence File, Reel 25, Norway. List Harriman do Roosevelta z 2 VII 1937 r.

${ }^{26}$ Po kilku latach współpracy w Oslo wystawiła mu bardzo pozytywną opinię, pisząc w samych superlatywach o jego profesjonalizmie, zaangażowaniu i lojalności. F. Jaffray Harriman, op. cit., s. 320 . 
Harriman złożyła listy uwierzytelniające królowi Haakonowi VII, po czym rozpoczęła swoje urzędowanie. Jednym z pierwszych jej obowiązków była organizacja dorocznego przyjęcia 4 VII 1937 r., a więc garden party w poselstwie z okazji amerykańskiego święta państwowego. Utrwalona przez poprzedników tradycja tych uroczystości w poselstwie USA cieszyła się dużym zainteresowaniem zarówno czynników rządowych, jak i szerszych kręgów Norwegów zabiegających o współpracę z placówką dyplomatyczną i rozwój stosunków amerykańsko-norweskich ${ }^{27}$.

Amerykańska dyplomatka szybko nawiązała liczne i serdeczne kontakty z Norwegami, jak również z korpusem dyplomatycznym w Oslo. Od początku zadbała o dobre relacje z brytyjskim ambasadorem Cecilem Dormerem, który - dzięki królowej Maud, Brytyjce - miał szczególnie bliskie stosunki z dworem królewskim. Podtrzymywała też, z czasem rozbudowane, kontakty z innymi dyplomatami akredytowanymi w Oslo, co było niezwykle przydatne w jej pracy dyplomatycznej.

Od początku swojej misji w Norwegii pani poseł wiele uwagi poświęcała na poznanie historii kraju, jego ówczesnej sytuacji gospodarczo-politycznej, jak też życia codziennego Norwegów. Uczestniczyła w rozlicznych ceremoniach i spotkaniach, nawiązując kontakty z członkami rządu, Stortingu, miejscowa elita gospodarczo-polityczna, a także rodziną królewską. Organizowała oficjalne uroczystości w poselstwie, brała udział w podobnych przyjęciach wydawanych przez placówki dyplomatyczne w Oslo, a także w okazjonalnych spotkaniach organizowanych przez rozmaite stowarzyszenia norwesko-amerykańskie. Często też gościła członków rodziny i przyjaciół oraz rodaków odwiedzających Skandynawię zazwyczaj w sprawach biznesowych. Udzielała się także w społeczności amerykańskiej w Oslo, wygłaszając odczyty m.in. w Klubie Amerykańskich Kobiet ${ }^{28}$.

Florence Harriman dosyć szybko pozyskała sympatię swoich gospodarzy zarówno z kręgów rządowych, jak i szerszych rzesz Norwegów. Odbywała regularne spotkania $z$ ministrem spraw zagranicznych Halvdanem Kohtem, historykiem z wykształcenia i profesorem na uniwersytecie w Oslo, wpływowym politykiem Partii Pracy, z którym często omawiała sytuację międzynarodowa. Był on pierwszym ministrem spraw zagranicznych Norwegii, który podczas swojej wizyty w $1937 \mathrm{r}$. dostapił zaszczytu rozmowy z Rooseveltem ${ }^{29}$. I to Harriman $\mathrm{w}$ dużej mierze należy przypisać fakt, że doszło do tego spotkania w Białym Domu, o które osobiście zabiegała. Warto też dodać, że pani poseł - o czym świadczy korespondencja dyplomatyczna - niejednokrotnie

${ }^{27}$ Zob. https://history.state.gov/departmenthistory/people/harriman-florence-jaffray-hurst (dostęp: 14 VIII 2018); F. Jaffray Harriman, op. cit., s. 59.

${ }^{28}$ F. Jaffray Harriman, op. cit., s. 75-95, 101 i n.

${ }^{29}$ S. Skard, Trans-Atlantica. Memoirs of a Norwegian Americanist, Oslo-Bergen-Tromsǿ 1978, s. 32; RIAS, President Franklin D. Roosevelt's Office Files, 1933-1945. Part 2: Diplomatic Correspondence File, Reel 25, Norway. List Harriman do Roosevelta z 20 X 1937 r. 
pomagała norweskim politykom, naukowcom i biznesmenom udającym się do USA w nawiązywaniu kontaktów z amerykańskimi czynnikami rządowymi, ośrodkami naukowymi i działaczami gospodarczymi.

Już pierwsze zapytania skierowane do Harriman przez amerykańskich dziennikarzy dotyczyły stanu rokowań o amerykańsko-norweskiej umowie handlowej, czemu - jak się miało okazać - poświęcała potem szczególnie wiele uwagi. I kwestie te oraz sprawy związane z imigracja w dużej mierze zdominowały jej poczynania na placówce w Oslo. Kryzys gospodarczy i narzucone przez USA wysokie taryfy celne powodowały bowiem liczne utrudnienia we wzajemnym handlu ${ }^{30}$.

Pobyt na placówce w Oslo wypełniły Harriman w dużej mierze zabiegi podejmowane już od kilku lat w sprawie podpisania traktatu handlowego. Niemal każdego tygodnia powracała bowiem kwestia amerykańskich ograniczeń celnych, a w szczególności wysokich taryf na tran wielorybi. Uderzało to w żywotne interesy ok. 40 tys. Norwegów mających swoje biznesy z tym związane. Norwegia, jak argumentował poseł, zmuszona była do szukania innych rynków zbytu, m.in. w Niemczech ${ }^{31}$.

Mimo podejmowanych starań Harriman nie udało się doprowadzić do finalizacji rokowań w sprawie traktatu handlowego, a swoje zabiegi nazwała nie bez powodu „unfinished business”32. Ale wymiana handlowa, mimo ówczesnych utrudnień i amerykańskich restrykcyjnych przepisów celnych, nie uległa pod koniec lat trzydziestych drastycznym zmianom, bowiem Stany Zjednoczone były ważnym partnerem, zajmując trzecie miejsce po Wielkiej Brytanii i Niemczech. Historia Norwegii wiąże się ściśle i nierozłącznie z rozwojem floty morskiej, która zawsze odgrywała ważną rolę w życiu gospodarczym kraju. W latach trzydziestych XX w. flota handlowa Norwegii zajmowała trzecie miejsce w świecie po USA i Wielkiej Brytanii ${ }^{33}$.

W korespondencji dyplomatycznej Harriman z centrala w Waszyngtonie, a zwłaszcza w rozmowach posła norweskiego Wilhelma Morgenstierne'a z sekretarzem stanu Cordellem Hullem powracała nieraz sprawa roszczeń finansowych Christoffera Hanneviga, wynikających z podpisanych przez niego w sierpniu 1917 r. 27 kontraktów z Amerykanami. Przez wiele lat domagał się on odszkodowań od USA z tytułu poniesionych strat. Hannevig swoich praw do odszkodowań dochodził także w Stałym Trybunale Sprawiedliwości Międzynarodowej w Hadze, który uznał zasadność części jego roszczeń, co nie

${ }^{30}$ W.S. Cole, op. cit., s. 64-65.

${ }^{31}$ Zob. korespondencja dyplomatyczna, rozmowy i memoranda posła Wilhelma Morgenstierne'a, w: Foreign Relations of the United States (dalej: FRUS), Washington 1955, FRUS, 1937, t. II, s. 517-524; FRUS, 1938, t. II, Washington 1956, s. 619-634.

${ }^{32}$ F. Jaffray Harriman, op. cit., s. 40-42.

${ }^{33}$ W.S. Cole, op. cit., s. 54. Norwegia importowała z USA głównie auta i akcesoria samochodowe, opony, wyroby naftowe, tekstylia, tytoń, świeże i suszone owoce oraz artykuły mięsne, zaś eksportowała celulozę, ryby i produkty rybne, tran i aluminium. 
usatysfakcjonowało Norwega, wciąż interweniującego kanałami dyplomatycznymi w Oslo i Waszyngtonie. W związku z rozmowami i pismami posła Morgenstierne'a do Departamentu Stanu sprawa ta powracała w kolejnych latach ${ }^{34}$. Ale warto zauważyć, że kwestia ta, choć kłopotliwa i wciąż pojawiająca się na nowo, nie wpłynęła w zasadniczy sposób na norwesko-amerykańskie relacje bilateralne.

Ważnym czynnikiem we wzajemnych stosunkach była imigracja Norwegów do USA, która osiagnęła swój szczyt pod koniec XIX w. ${ }^{35}$ Sprawy imigracyjne odgrywały też istotną rolę $\mathrm{w}$ relacjach bilateralnych w kolejnych dekadach, mimo amerykańskich ograniczeń imigracyjnych z 1921 i 1924 r., które wpłynęły również na zmniejszenie napływu Norwegów za ocean. Norwescy politycy podejmowali próby, by zaradzić dalszym ograniczeniom imigracyjnym i przeciwdziałać utrudnieniom wizowym. Carl J. Ambro, przewodniczacy Stortingu, odbył kilka wizyt do USA, zabiegając o lepsze traktowanie rodaków starających się o wizy i wyjazd za ocean oraz o zwiększenie dla nich limitu imigracyjnego ${ }^{36}$.

Społeczność amerykańskich Norwegów osiągnęła do tego czasu znacząca pozycję gospodarczo-polityczną na gruncie amerykańskim. Ich rozliczne organizacje i stowarzyszenia kultywowały pamięć o kraju przodków i podtrzymywały związki z Norwegia. Od połowy lat dwudziestych XX w. diaspora norweska w USA, wydatnie wspierana przez rząd w Oslo, uaktywniła się $\mathrm{w}$ propagowaniu więzi z krajem i - na fali nacjonalizmu - zaangażowała się również w budowę wizerunku „wielkiej Norwegii”. Miało to duże znaczenie dla tożsamości amerykańskich Norwegów, a poczucie dumy z osiagnięć kraju przodków wzmacniano m.in. przez szeroko propagowany już od lat osiemdziesiątych XIX w. mit i kult Leifa Ericssona (Leiva Eirikssona) oraz organizowane uroczystości na gruncie amerykańskim. Amerykańscy Norwegowie podtrzymywali ożywione relacje, także biznesowe z krajem pochodzenia, nierzadko też goszcząc w poselstwie amerykańskim w Oslo ${ }^{37}$.

${ }^{34}$ Ibidem, s. 54-56; RIAS, The Papers of Cordell Hull, Reel 31, Norway. Memoranda i obszerna korespondencja na temat tzw. Hannevig claims pomiędzy sekretarzem stanu Hullem i posłem Morgenstierne'em z lat 1933-1939 są ciekawym materiałem zasługującym na osobne opracowanie.

${ }^{35}$ O.S. Lovoll, The Promise of America. A History of the Norwegian-American People, Minneapolis-London 1999, s. 35. Autor podaje, że w latach 1846-1890 do USA przybyło blisko 513 tys. Norwegów, a potem - do 1930 r. - kolejnych ok. 339 tys. Szacuje się, że po I wojnie światowej społeczność norweska w USA liczyła ok. 1,8-2 mln. Był to zatem duży odpływ ludności z kraju liczącego w latach 1920-1940 ok. 2,6-2,9 mln mieszkańców. Z polskich prac warto odnotować książkę Krystyny Szelagowskiej, Listy z Ameryki. Z dziejów emigracji norweskiej do Stanów Zjednoczonych w XIX wieku, Białystok 2017.

${ }^{36}$ W.S. Cole, op. cit., s. 57-61. Kontyngent imigracyjny zmniejszył się z 12202 do 6453 w połowie lat dwudziestych, a potem jeszcze uległ zmniejszeniu.

${ }^{37}$ D.W. Olson, Vikings across Atlantic. Emigration and the Building of a Greater Norway, 1860-1945, Minneapolis 2013, s. 175-185. W 1925 r. uroczyście świętowano 100-lecie norweskiej emigracji do USA, propagując kult przodków i osiagnięcia rodaków. W $1929 \mathrm{r}$. Wisconsin ustanowił Ericsson Day, a potem kilka innych stanów, w których ludność 
Amerykańska dyplomatka fascynowała się przeszłością wikingów i w ogóle historią Norwegów. Niezwykle życzliwie wypowiadała się na temat kraju swego urzędowania, zachwycając się jego niezwykłym krajobrazem, zwłaszcza fiordami i pracowitymi, przedsiębiorczymi mieszkańcami, z którymi chętnie nawiązywała kontakt podczas swoich dosyć częstych podróży po kraju. Harriman odwiedzała szkoły i muzea, a także farmy lisów i gospodarstwa wiejskie specjalizujące się w hodowli bydła itd. Podczas wizyt w odległych nieraz wiejskich zakątkach podziwiała misterną sztukę haftu i koronkarstwa, będącą dla wielu Norwegów podstawowym źródłem dochodu ${ }^{38}$.

W pracy dyplomatycznej Harriman od początku swego urzędowania sporo uwagi poświęcała również zabiegom o przyznanie Pokojowej Nagrody Nobla dla sekretarza stanu Cordella Hulla, o czym świadczą jej liczne raporty. Prowadziła ożywioną korespondencję z Departamentem Stanu, zwłaszcza z Williamem Phillipsem, a także z prezydentem Rooseveltem, który osobiście interesował się tą kwestią i zabiegał o wylansowanie kandydatury Hulla. Ale od początku, jak informowała pani poseł zwierzchników w Waszyngtonie w 1937 r., pojawili się silni konkurenci do tej nagrody, m.in. lord William Cecil, także Fridtjof Nansen ${ }^{39}$. Również w kolejnych latach, mimo amerykańskich starań, sekretarz stanu tej nagrody nie otrzymał ${ }^{40}$.

Misję dyplomatyczną w Norwegii Florence Harriman pełniła w niesprzyjających okolicznościach ze względu na głęboki światowy kryzys gospodarczy i napięcia międzynarodowe $\mathrm{w}$ drugiej połowie lat trzydziestych, a potem II wojnę światową. Ale swoją praca i zaangażowaniem zaskarbiła sobie szybko zarówno sympatię gospodarzy, jak też uznanie w kręgach rządowych w Waszyngtonie ${ }^{41}$. W amerykańskich mediach pisano o niej życzliwie, wskazując na pozytywne rezultaty jej pracy dyplomatycznej w podtrzymywaniu dobrych stosunków bilateralnych ${ }^{42}$.

pochodzenia norweskiego upomniała się o swego legendarnego bohatera, który jakoby już w X w. dotarł do wybrzeży Ameryki.

${ }^{38}$ F. Jaffray Harriman, op. cit., s. 115-138, 175-184.

${ }^{39}$ RIAS, President Franklin D. Roosevelt's Office Files, 1933-1945. Part 2: Diplomatic Correspondence File, Reel 25, Norway. Raporty Harriman z VII-XII 1937 r.

${ }^{40}$ Ibidem. Wiele raportów Harriman i jej korespondencja z prezydentem z 1938 i 1939 r. dotyczyła dalszych zabiegów o przyznanie Pokojowej Nagrody Nobla amerykańskiemu sekretarzowi stanu. 13 I 1938 r. Roosevelt wystosował nawet specjalne pismo do Komitetu Noblowskiego, osobiście zgłaszając kandydaturę Hulla do tej nagrody za „zasługi dla pokoju i rozwoju dobrosasiedzkiej polityki w Zachodniej Hemisferze”. Ale i wówczas tej nagrody Amerykanowi nie przyznano. Otrzymał ją dopiero w 1945 r., jak argumentowano, za usilne starania w przezwyciężeniu izolacjonizmu na gruncie amerykańskim, wysiłki pokojowe oraz zaangażowanie w tworzeniu ONZ.

${ }^{41}$ W.S. Cole, op. cit., s. 53.

${ }^{42}$ M. Hornaday, Dear Madame Minister, „Christian Science Monitor”, 5 VII 1938, s. 3; Woman Envoy, „Newsweek”, 22 IV 1940, s. 28; M. David, Just Like Daisy, Extraordinary Mrs. J.B. Harriman, American Minister to Norway, „Saturday Evening Post”, 22 VI 1940, s. 24-25. 
Harriman wspominała potem - i nie była to bynajmniej kurtuazja - że jej praca dyplomatyczna w Oslo stała się łatwiejsza dzięki temu, że kilka lat wcześniej Ruth Bryan Owen pokonała rozliczne bariery w Departamencie Stanu. To ona przełamała „chłód i opór” czynników rządowych i przetarła ten trudny szlak nie tylko dla niej, ale wszystkich Amerykanek aspirujących do pracy $\mathrm{w}$ dyplomacji ${ }^{43}$.

W trakcie swojej misji w Oslo Harriman wyjeżdżała nieraz za granicę, odwiedzając amerykańskie placówki i informując potem szczegółowo Departament Stanu i prezydenta o nastrojach w państwach europejskich. Warto pamiętać, że Roosevelt chętnie podtrzymywał korespondencję z dyplomatami i korzystał z przekazywanych przez nich informacji w listach i raportach adresowanych bezpośrednio do niego. Harriman należała do tego grona, o czym świadczy ich korespondencja, w tym także serdeczne listy prezydenta kierowane do „Daisy”, jak się do niej zwracał ${ }^{44}$.

We wrześniu 1937 r. Harriman na zaproszenie amerykańskiego posła Freda Deeringa odwiedziła Sztokholm, zapoznając się bliżej z położeniem geopolitycznym regionu i polityką państw skandynawskich. W sierpniu $1938 \mathrm{r}$. odbyła dziesięciodniową wizytę w Wielkiej Brytanii, a we wrześniu 1938 r. spędzała wakacje z wnuczką w Paryżu, gdzie ją zastały wieści o konferencji w Monachium. Zapamiętała niepokój i nastroje niepewności, a potem ogromna ulgę i radość okazywaną powszechnie, że „pokój został zachowany i nie będzie wojny!" 45

Florence Harriman podtrzymywała bliskie kontakty z dworem królewskim, gdzie okazjonalnie gościła. Uczestniczyła też - w imieniu swego rządu i jako specjalna wysłanniczka prezydenta USA - w ceremonii pogrzebowej królowej Maud, która zmarła 20 XI 1938 r. w Londynie. Brała również udział w spotkaniu w pałacu królewskim i uroczystości upamiętniającej zmarła, z którą miała serdeczne kontakty. Szczegółowo informowała o tym Roosevelta, wskazując, że jego kondolencje i wyrazy współczucia dla rodziny królewskiej oraz zaproszenie przez Rooseveltów pary książęcej do USA spotkały się z pozytywnym odbiorem w Oslo. Jak zapewniała dyplomatka, fakty te były potwierdzeniem serdecznych kontaktów osobistych króla Haakona VII i prezydenta Roosevelta, jak też przyjaznych relacji norwesko-amerykańskich ${ }^{46}$.

${ }^{43}$ F. Jaffray Harriman, op. cit., s. 37-38.

${ }^{44}$ RIAS, President Franklin D. Roosevelt's Office Files, 1933-1945. Part 2: Diplomatic Correspondence File, Reel 25, Norway.

${ }^{45}$ Ibidem. Raport Harriman do Roosevelta z 15 VIII 1938 r.; F. Jaffray Harriman, op. cit., s. $85-86,97-100$.

${ }^{46}$ RIAS, President Franklin D. Roosevelt's Office Files, 1933-1945. Part 2: Diplomatic Correspondence File, Reel 25, Norway. Raport Harriman do Roosevelta z 7 oraz 19 XII 1938 r. Jeszcze korespondencja Harriman z Departamentem Stanu i prezydentem z marca 1939 r. dotyczy pogrzebu królowej Maud i osobistych podziękowań króla Haakona VII przesłanych na ręce Roosevelta. 
18 III 1939 r. Harriman w towarzystwie m.in. posła duńskiego Kauffmanna oraz konsula generalnego Askviga odbyła planowaną wcześniej podróż po malowniczych fiordach za koło polarne, na Lofoty (Lofoten), o czym szczegółowo poinformowała zarówno sekretarza Hulla, jak i prezydenta ${ }^{47}$. Była to niezwykła wyprawa do Lofoten Fisheries, pełna ciekawych wrażeń i licznych spotkań z rybakami oraz mieszkańcami odległej Północy, dla których Harriman okazała się kimś ważnym i bliskim, ale przede wszystkim niezwykła atrakcja bowiem żaden amerykański dyplomata wcześniej nie odwiedził tych odległych od stolicy miejsc. Jak zabawnie to opisała, rybacy chcieli z bliska zobaczyć amerykańskiego posła, ale przeżyli niemałe zdumienie, bo... przed nimi stała kobieta ${ }^{48}$. Nie przeszkodziło to w żadnej mierze w nawiązaniu z nimi serdecznego kontaktu. Pani poseł uczestniczyła w niecodziennym wydarzeniu, bowiem - na okoliczność tej wizyty - zgromadzono tam ok. 4 tys. łodzi i kutrów rybackich, które brały udział w konkursie połowów dorsza. Był to prawdziwy festiwal nawiąujący do najlepszych tradycji rybołówstwa norweskiego, jak też, a może przede wszystkim, sposób zademonstrowania potęgi Norwegii w tej dziedzinie. Harriman osobiście brała udział w tych zawodach, co spotkało się z niezwykle ciepłym przyjęciem rybaków, a potem też lokalnych mediów, sympatycznie opisujących wizytę dostojnego gościa. Dyplomatka przeszła tam niezwykły rytuał i „chrzest” na „szefa łodzi rybackiej” i „prawdziwego wikinga” ${ }^{49}$.

W kolejnych dniach Harriman odbyła dalszą podróż po norweskich fiordach, odwiedzając wiele odległych miejscowości, w których spotykała się z mieszkańcami. Wszędzie przyjmowano ją niezwykle serdecznie i z wielkimi honorami. Gospodarze zapewniali ja o szczególnych więzach i przyjaźni z Ameryka, deklarując chęć rozwoju stosunków norwesko-amerykańskich. W Trondheim odbyła liczne spotkania, m.in. z nowo powołanym Towarzystwem Brytyjsko-Amerykańskim oraz stowarzyszeniami kobiecymi. Wygłosiła kilka odczytów na temat amerykańskiej i norweskiej demokracji oraz udzieliła wywiadów w lokalnej prasie i radiu. Wykorzystała każda sposobność, by promować politykę wewnętrzną i zagraniczną Roosevelta. Wskazywała na pokojowość amerykańskiej polityki i dużą rolę kobiet w tym względzie. Nadmieniła, że prawa kobiet były specjalną troską rządu, o co szczególnie dbały dwie niezwykłe kobiety: Eleanor Roosevelt i Frances Perkins. O first lady, o której rolę w prezydenturze pytały Norweżki, mówiła z uznaniem i szczególnie serdecznie, dodając: „Podziwiam ją za jej niezwykłe zdolności, inicjatywę, odwagę i wysiłek, by polepszyć warunki życia dla obywateli mniej uprzywilejowanych" ${ }^{\text {. }}$.

\footnotetext{
${ }^{47}$ Ibidem. Raporty Harriman do Hulla oraz Roosevelta datowane 29 III 1939 r.

${ }^{48}$ F. Jaffray Harriman, op. cit., s. 165-170.

${ }^{49}$ RIAS, President Franklin D. Roosevelt's Office Files, 1933-1945. Part 2: Diplomatic Correspondence File, Reel 25, Norway. Raport Harriman do Roosevelta z 29 III 1939 r.

${ }^{50}$ Ibidem.
} 
W szczegółowym sprawozdaniu z tego pobytu, zarówno do Hulla, jak i Roosevelta, Harriman podkreślała znaczenie wizyty dla ocieplenia i dalszego rozwoju wzajemnych stosunków. Załączyła tłumaczenia tekstów, które ukazały się w lokalnych mediach norweskich nagłaśniających wizytę amerykańskiej dyplomatki. Jak pisano, parafrazując słynne zdanie: „Pani poseł przybyła, zobaczyła i podbiła Norwegów" ${ }^{\text {11. }}$.

Wiosna 1939 r. w korespondencji dyplomatycznej Harriman z Departamentem Stanu i osobiście z prezydentem Rooseveltem często pojawiała się planowana wizyta w USA księcia Olafa z małżonką Martą. Na zaproszenie prezydenta w dniach 28-30 IV 1939 r. para książęca gościła w Hyde Parku, a potem odbyła turę objazdowa po USA. W trakcie dwu i półmiesięcznego pobytu norwescy goście odwiedzili kilkadziesiąt stanów, m.in. Wisconsin, Michigan, Minnesotę, Iowa, Dakotę Północną i Południowa, Kalifornię i Waszyngton. Byli serdecznie przyjmowani i uczestniczyli w rozlicznych uroczystościach oraz imprezach integrujących społeczność norwesko-amerykańską wokół idei narodowej i kultu Leifa Ericssona ${ }^{52}$.

31 VII 1939 r. Harriman informowała prezydenta Roosevelta o „wielkim sukcesie i triumfalnej wizycie pary książęcej w USA", jak to przedstawiano w mediach norweskich, mającej odwiedzić aż 34 stany. Nie bez satysfakcji wzmiankowała, że z okazji powrotu księcia Olafa z małżonką Martą na uroczystym obiedzie w pałacu królewskim była jedyną osobą spośród gości z korpusu dyplomatycznego. Informowała też prezydenta o odbytych rozmowach na temat „nieciekawej sytuacji w Europie” i „pesymistycznych nastrojach” w pałacu królewskim w Oslo ${ }^{53}$.

Kilka dni później, 2 VIII 1939 r. Roosevelt dziękował „Daisy” za przygotowanie i pomoc w organizacji wizyty księcia Olafa z małżonką Marta, która tak pomyślnie wypadła i wzmocniła przyjazne relacje norwesko-amerykańskie. Wyraził też swój niepokój z powodu sytuacji w Europie, która najwyraźniej zmierzała do wojny ${ }^{54}$.

W kolejnych raportach Harriman informowała centrale w Waszyngtonie o wzroście napięć w Europie i niebezpieczeństwie wybuchu konfliktu zbrojnego. Obserwowała coraz trudniejszą sytuację Norwegii, której rząd starał się z niemałym trudem zachowywać neutralność. Szczegółowo nieraz pisała o jego poczynaniach, ale i coraz realniejszej groźbie rozszerzenia konfliktu również na Skandynawię.

W sierpniu 1939 r. Harriman odbyła z przyjaciółmi krótka, pięciodniowa wycieczke do ZSRR. Jak wspominała, nie był to planowany wyjazd, ale wizę otrzymała bez przeszkód i „zupełnie ekspresowo”. Po krótkim pobycie

\footnotetext{
${ }^{51}$ Ibidem.

${ }^{52}$ Ibidem. Raport Harriman z 28 IV 1939 r. oraz 31 VII 1939 r.; W.S. Cole, op. cit., s. 77-78.

${ }^{53}$ RIAS, President Franklin D. Roosevelt's Office Files, 1933-1945. Part 2: Diplomatic Correspondence File, Reel 25, Norway. Raport Harriman z 31 VII 1939 r.

${ }^{54}$ Ibidem. Pismo Roosevelta do Harriman z 2 VIII 1939 r.
} 
w Sztokholmie i Tallinie równie pośpiesznie zwiedzała Leningrad i Moskwę, goszczac też w amerykańskiej ambasadzie. Sympatycznie napisała o wrażeniach z tej wyprawy, choć wyraźnie odcinała się od jakichkolwiek ocen sytuacji politycznej w ZSRR ${ }^{55}$.

Ostatnim przystankiem w podróży amerykańskiej dyplomatki był Gdańsk, gdzie - zapewne obserwujacc nastroje - przypomniała o głoszonej od lat tezie znanego i poczytnego publicysty Franka H. Simondsa, że „polski korytarz” stanie się przyczyną kolejnej wojny ${ }^{56}$. Odwiedziła również Sopot i Gdynię będąca - jak dodała - „dumą Polskiej Republiki”. Podczas tej podróży uzmysłowiła sobie pełniej wielowiekową rywalizację sasiadów o dostęp do Bałtyku. I dodała, że podróż była dla niej prawdziwą lekcja geografii. „Miejsca, ludzie, granice, wszystko to stało się dla mnie realne. [...]. Ale niemiecko-radziecki pakt był ostatnią rzecza, której mogłam się spodziewać"57, jak skomentowała podpisany 23 VIII 1939 r. pakt Ribbentrop-Mołotow.

Napięcia i złowieszcze wieści nadchodzące również z innych placówek dyplomatycznych nie pozostawiały już większych nadziei na zachowanie pokoju. Napaść III Rzeszy na Polskę zapoczątkowała kolejną wojnę i dramaty ludzkie o niewyobrażalnych rozmiarach, jak pisała Harriman. W następnych tygodniach z niepokojem obserwowała coraz trudniejsze, jak wspominała, położenie państw skandynawskich starających się zachować neutralnośćc ${ }^{58}$.

W listopadzie 1939 r. doszło do sporych napięć w stosunkach USA z III Rzeszą z powodu niemieckich oskarżeń o nieprzestrzeganie i wręcz łamanie neutralności przez Amerykanów. Niemcy, pod pretekstem zwalczania kontrabandy na neutralnych wodach, przejęli amerykański frachtowiec „City of Flint" i sprowadzili go do portu w Bergen. To w dużym stopniu dzięki zabiegom Florence Harriman udało się wynegocjować warunki zwolnienia statku, który w końcu powrócił do USA ${ }^{59}$. Jej poczynania i zabiegi dyplomatyczne spotkały się z uznaniem w kręgach rządowych, jak również zostały docenione przez amerykańską opinię publiczna. Ona sama, dumna ze skutecznej akcji, stale uczyła się - jak pisała w raportach - funkcjonowania na placówce neutralnego kraju, ale zagrożonego coraz bardziej w związku z poszerzaniem teatru działań wojennych w Europie i ekspansja niemiecka oraz radziecka po napaści 30 XI 1939 r. na Finlandię. Z autentyczną troską o los Norwegów zagrożonych ewentualną agresją dyplomatka pisała do prezydenta, sondując możliwość zakupu przez nich niszczycieli w $\mathrm{USA}^{60}$.

${ }^{55}$ F. Jaffray Harriman, op. cit., s. 189-206.

${ }^{56}$ F.H. Simonds, Can Europe Keep the Peace?, London 1931.

${ }^{57}$ F. Jaffray Harriman, op. cit., s. 207-208.

${ }^{58}$ Ibidem, s. 213-214.

${ }^{59}$ Ibidem, s. 229-238.

${ }^{60}$ RIAS, President Franklin D. Roosevelt's Office Files, 1933-1945. Part 2: Diplomatic Correspondence File, Reel 25, Norway. Pismo Harriman do Roosevelta z 5 XII 1939 r., na które odpowiedział odmownie 9 I 1940 r., powołując się na ustawy o neutralności. 
W kolejnych miesiącach Harriman była też swego rodzaju pośrednikiem pomiędzy Rooseveltem a księciem Olafem, który zabiegał o amerykańska pomoc finansowa i wojskową krajowi coraz bardziej osaczanemu przez wrogów zewnętrznych i V kolumnę. Wiosną 1940 r. dyplomatka pisała o „podstępnych i dywersyjnych" działaniach Niemców na terenie Norwegii i wzrastającym zagrożeniu z ich strony. Wspominała potem, że 7 kwietnia poseł III Rzeszy zaprosił korpus dyplomatyczny na uroczystą kolację, podczas której wyświetlono film o bombardowaniu i straszliwych zniszczeniach Warszawy. Był to wyreżyserowany pokaz i przekaz dla świata (i tak to odebrano), co się stanie z narodem, który sprzeciwi się III Rzeszy ${ }^{61}$.

Florence Harriman była pierwszą dyplomatka, która poinformowała Waszyngton o nagłym ataku Niemiec 9 IV 1940 r. na Norwegię, a także Danię. Formalnie zatem zakończyła swoje urzędowanie w tym kraju, choć kilka kolejnych tygodni wytrwale zajmowała się przede wszystkim ewakuacja z Norwegii rodaków, a zwłaszcza kobiet i dzieci ${ }^{2}$. Pisała o tym w raportach do Departamentu Stanu i Roosevelta, z którym konsultowała kwestie związane z ewakuacja Amerykanów, a także członków norweskiej rodziny królewskiej zaproszonych osobiście przez prezydenta do przyjazdu do $\mathrm{USA}^{63}$.

We wszystkich sprawach dotyczących zamknięcia poselstwa w Oslo i ewakuacji do Szwecji Harriman współpracowała z poselstwem w Sztokholmie. Tam też mieściła się przeniesiona, po agresji ZSRR na Finlandię, Amerykańska Misja w Helsinkach, kierowana przez mjr. Franka Hayne’a, który do pomocy miał attaché ds. lotnictwa kpt. Roberta M. Loseya. Po ataku Niemiec na Norwegię amerykańscy wojskowi zostali obserwatorami wojny, która poszerzała swój zasięg w Skandynawii. Zgodnie z instrukcją z Waszyngtonu kpt. Losey otrzymał polecenie, by pomóc Florence Harriman w ewakuacji do Sztokholmu amerykańskiego poselstwa z Oslo i osób z nim związanych ${ }^{64}$.

21 IV 1940 r. kpt. Losey, wykonujac swoje zadanie, zginął w miejscowości Dombås podczas ostrzału przez niemieckie samoloty. Śmierć młodego wojskowego, którego nawet nie zdążyła poznać bliżej, jak wspominała, była prawdziwym dla niej szokiem. Osobiście zajęła się organizacją uroczystości pogrzebowej w Sztokholmie. Uczestniczyli w niej akredytowani w Szwecji

${ }^{61}$ Ibidem. Raporty Harriman do Departamentu Stanu z III-IV 1940 r.

${ }^{62}$ Ibidem. Pismo Harriman do Roosevelta z 30 IV 1940 r., w którym dziękowała prezydentowi za powierzenie jej tak zaszczytnej misji dyplomatycznej w Oslo i bycie „maleńkim trybikiem” w jego administracji; https://history.state.gov/departmenthistory/people/harriman-florence-jaffray-hurst (dostęp: 14 VIII 2018); https://www.britannica.com/biography/ Florence-Jaffray-Harriman (dostęp: 14 VIII 2018).

${ }^{63}$ RIAS, President Franklin D. Roosevelt's Office Files, 1933-1945. Part 2: Diplomatic Correspondence File, Reel 25, Norway. Raporty Harriman do Roosevelta z IV-V 1940 r., już ze Sztokholmu.

${ }^{64}$ J.M. Cleverley, The First American Official Killed in This War, https://photos.state.gov/ libraries/finland/788/pdfs/cleverley.pdf (dostęp: 15 VIII 2018). 
dyplomaci, przedstawiciele rządu szwedzkiego i norweskiego oraz przebywający tam Amerykanie i inni cudzoziemcy ${ }^{65}$. Jak napisał potem „New York Times”, kpt. Losey był pierwszym „amerykańskim wojskowym, który zginął na służbie w wojnie, w której USA jeszcze nie brały udziału"66.

O bohaterskiej walce Norwegów w obronie ojczyzny informowała Harriman Waszyngton już ze Sztokholmu. Miała regularny tam kontakt z politykami norweskimi przekazujacymi jej informacje o kolejnych walkach z Niemcami i wsparciu ich przez angielskie, francuskie i polskie oddziały ekspedycyjne, które po kilku tygodniach opuściły Norwegię. Z niepokojem obserwowała rozwój sytuacji w okupowanym kraju i powołanie kolaboracyjnego rządu z premierem Vidkunem Quislingiem, a potem kapitulację Norwegów, a także emigrację króla Haakona VII wraz z rządem do Londynu ${ }^{67}$.

Należy pamiętać, że Sztokholm był wówczas ważnym ośrodkiem informacyjnym, bowiem zgromadzeni tam cudzoziemscy dziennikarze informowali świat o wojnie w Skandynawii. Stolica Szwecji, jako kraju neutralnego, stała się zarazem ważnym punktem ewakuacyjnym dla Amerykanów, a także Skandynawów, starających się o wyjazd do USA. Harriman, dzięki wydatnej pomocy ze strony posła Freda Sterlinga, udało się zorganizować ewakuację Amerykanów, zwłaszcza kobiet i dzieci. Warto też dodać, że w ewakuacji cudzoziemców, a w szczególności Norwegów, pani poseł korzystała czasem z pomocy ambasador Kołłątaj, m.in. w uzyskiwaniu wiz radzieckich i transporcie przez ZSRR i Japonię do USA ${ }^{68}$.

12 VIII 1940 r., dzięki interwencji Harriman w Departamencie Stanu i sprawnie zorganizowanej pomocy ze strony rządu amerykańskiego, blisko 900 osób odpłynęło z Pieczengi (Petsamo) na przysłanym przez rząd amerykański okręcie wojennym „U.S. American Legion”. Wśród pasażerów przeważali Amerykanie, w tym zwłaszcza wiele rodzin z dziećmi. W grupie tej znaleźli się także księżna Marta z dziećmi, żona i troje dzieci posła Sterlinga oraz cudzoziemcy z wielu krajów, których wojna zastała w państwach skandynawskich ${ }^{69}$.

28 VIII $1940 \mathrm{r}$. w porcie nowojorskim przybyłych witali bardzo serdecznie przedstawiciele Departamentu Stanu, norweski poseł, dziennikarze i licznie zgromadzeni tam Amerykanie. Szczególnie uroczyście i z honorami przyjmowano

${ }^{65}$ F. Jaffray Harriman, op. cit., s. 287-289; RIAS, President Franklin D. Roosevelt's Office Files, 1933-1945. Part 3: Departmental Correspondence File, Reel 20. Pisma Jamesa Farley'a do prezydenta z 13 IV 1940 r. oraz 25 IV 1940 r. z informacją na temat śmierci Roberta Loseya i walkach w Norwegii.

${ }^{66}$ J.M. Cleverley, op. cit. W 1987 r. mieszkańcy Dombås, gdzie zginął amerykański attaché, odsłonili pomnik upamiętniający Amerykanina.

${ }^{67}$ F. Jaffray Harriman, op. cit., s. 290-299; RIAS, The Papers of Cordell Hull, Reel 31, Norway. Memoranda i korespondencja posła Morgenstierne'a z Hullem z kwietnia 1940 r.

68 S. Skard, op. cit., s. 34-38; F. Jaffray Harriman, op. cit., s. 304-306.

${ }^{69}$ F. Jaffray Harriman, op. cit., s. 307-317. 
powracająca do kraju - jak odnotowano w prasie - „dzielną i odważna panią poseł, której udało się uratować setki uchodźców z ogarniętej wojną Europy”70.

Obowiązki wynikajace z wcześniejszego urzędowania w Oslo Harriman definitywnie zakończyła w styczniu 1941 r., podejmując nowe zadania. W uznaniu jej zasług dla rozwoju stosunków bilateralnych i za wydatna pomoc Norwegom po napaści III Rzeszy król Haakon VII w lipcu 1942 r. nadał jej Wielki Krzyż Orderu Świętego Olafa ${ }^{71}$, najstarsze i najwyższe norweskie odznaczenie.

Po powrocie do kraju ze Skandynawii Florence Harriman udzielała czasem wywiadów, wygłaszała odczyty w kampanii wyborczej Roosevelta w 1940 r. i przygotowywała pamiętniki, w których niezwykle ciepło i życzliwie pisała o trzech latach pracy w Norwegii, gościnnych gospodarzach, rozlicznych przyjaźniach oraz zdobytych tam doświadczeniach.

Warto wspomnieć, że Harriman uczestniczyła w przygotowaniu do druku bodaj pierwszej w języku angielskim książki o obozie koncentracyjnym w Oświęcimiu. Praca najpierw ukazała się w okupowanej Polsce w 1942 r., a po 2 latach w marcu 1944 r. w Nowym Jorku w wersji anglojęzycznej, o co zabiegali działacze polonijni ${ }^{72}$.

Po wojnie Florence Harriman nadal brała udział w życiu publicznym, uczestnicząc w pracy organizacji kobiecych, zwłaszcza wspierających wysiłki na rzecz zachowania pokoju. Organizowała wciąż przyjęcia w swoim domu, zapraszając ciekawych rozmówców i osobistości o bardzo różnych poglądach. Zachęcana przez przyjaciół starannie porządkowała papiery i dokumenty dotyczace jej działalności z lat 1912-1950. 25 IX 1957 r. przekazała je do kolekcji archiwalnej w Bibliotece Kongresu ${ }^{73}$.

18 IV 1963 r. prezydent John F. Kennedy - w uznaniu zasług - odznaczył Florence Harriman Presidential Citation of Merit. Przypomniał jej niezwykła,

70 „American Legion” Docks with Royal and Plebeian Refugees, „Life”, 9 IX 1940. Poinformowano o przybyciu ok. 870 podróżników, w przeważającej mierze Amerykanów oraz uchodźców norweskich i z innych krajów Europy. Zamieszczono też ciekawe zdjęcia zarówno „zwykłych” podróżnych, jak i pani poseł oraz norweskiej rodziny królewskiej, która - na zaproszenie Roosevelta - miała gościć w Hyde Parku.

71 W.S. Cole, op. cit., s. 54; Norway's King Gives Honor to U.S. Minister, „Wisconsin State Journal", 31 VII 1942, s. 8.

${ }^{72}$ N. Zarembina, F. Harriman, Oswiecim, camp of death (underground report), New York 1944. Harriman jako przewodnicząca American Free World Association napisała wprowadzenie do tej książeczki.

${ }^{73}$ Florence Jaffray Harriman. A Register of Her Papers In the Library of Congress, Manuscript Division, LC, Washington 1958. Cała jej spuścizna, uporządkowana chronologicznie, znajduje się w 29 pudłach archiwalnych (Containers 1-29). Jej bogata korespondencja z amerykańskimi politykami i dyplomatami oraz osobistościami z całego świata, jak też liczne miscellanea stanowią ciekawe i użyteczne źródło dla kolejnych pokoleń historyków zajmujących się dziejami USA. Pozostaje wyrazić nadzieję, że Florence Harriman doczeka się w końcu swojej biografii. 
wieloletnią służbę publiczną i zaangażowanie w budowę pokoju oraz promowanie idei wolności w świecie. Wysoko ocenił pracę dyplomatyczną Harriman w Norwegii „w trudnych i pełnych wyzwań czasach”. Jak podkreślił, dyplomatka wykazała się w swojej pracy i służbie dla kraju „osobista odwagą i niezwykła energią, czym zasłużyła na powszechne uznanie i wdzięczność rodaków ${ }^{74}$.

Florence Jaffray Harriman dożyła sędziwego wieku, otaczana sympatia i życzliwością Amerykanów. 97-letnia „Daisy” zmarła 31 VIII 1967 r. ${ }^{75}$, żegnana z honorami przez rodaków, w tym zwłaszcza Amerykanki, dla których była ucieleśnieniem kobiecego sukcesu i postacią legendarną.

\section{Streszczenie}

Florence Harriman (1870-1967) była znaną reformatorką i działaczką klubów kobiecych Partii Demokratycznej oraz zaangażowaną sufrażystką. Zwieńczenie jej działalności publicznej i błyskotliwej kariery stanowiła praca dyplomatyczna pod koniec lat trzydziestych. W $1937 \mathrm{r}$. prezydent Franklin D. Roosevelt powołał ją na stanowisko posła w Oslo, dzięki czemu przeszła do historii jako druga Amerykanka samodzielnie kierująca placówką dyplomatyczną USA.

W Norwegii Harriman spędziła trzy lata, angażując się w rozwój współpracy i podtrzymywanie dobrych amerykańsko-norweskich stosunków bilateralnych. Jej misję w Oslo przerwała agresja III Rzeszy na Norwegię 9 IV 1940 r. W kolejnych tygodniach - już ze Sztokholmu - dyplomatka organizowała ewakuację Amerykanów, a także członków rodziny królewskiej i cudzoziemców, których wojna zatrzymała w Skandynawii.

W uznaniu jej zasług dla narodu norweskiego król Haakon VII nadał jej w lipcu $1942 \mathrm{r}$. Wielki Krzyż Orderu Świętego Olafa. W 1963 r. prezydent John F. Kennedy odznaczył ja Presidential Citation of Merit za wieloletnią i ofiarną służbę oraz pracę dyplomatyczna.

\section{Florence Harriman and Her Diplomatic Work in Norway, 1937-1940}

Florence Harriman (1870-1967) was a well-known reformer and activist of women's clubs of the Democratic Party, and a committed suffragist. The height of her public activities and brilliant career was her diplomatic post at the end of the 1930s. In 1937 President Franklin D. Roosevelt appointed her minister to Oslo, which made her enter the pages of history as the second American woman at the head of a US diplomatic post.

In Norway, Harriman spent three years, contributing greatly to the development of bilateral American-Norwegian cooperation and good relations. Her mission to Oslo was interrupted by the Third Reich's aggression against Norway on 9 April 1940. In next few weeks she organised - from Stockholm - an evacuation of Americans as well as members of the royal family and foreigners trapped by the war in Scandinavia.

In recognition of her merits for Norwegian people, in July 1942 King Haakon VII decorated her with the Great Cross of Saint Olav Order. In 1963, President John F. Kennedy awarded her Presidential Citation of Merit for many years of devoted service and distinguished diplomatic work.

74 J.F. Kennedy, Remarks Upon Presenting a Presidential Citation of Merit to Mrs. Florence Harriman, www.presidency.ucsb.edu/ws/index.php?pid==9153 (dostęp: 18 VIII 2018).

${ }^{75}$ Daisy Harriman Dies; Democratic Party Legend, https://news.google.com/newspapers?id=zTIIAAAAIBAJ\&sjid=vAANAAAAIBAJ\&pg=1061,14685\&dq=daisy+harriman\&hl=en (dostęp: 12 VIII 2018). 


\section{Bibliografia}

Banner L.W., Women in Modern America. A Brief History, New York 1973.

Cole W.S., Norway and the United States, 1905-1955. Two Democracies in Peace and War, Ames 1989.

Downey K., The Women Behind New Deal. The Life of Frances Perkins, FDR's Secretary of Labor and His Moral Conscience, New York 2009.

Evans S.M., Born for Liberty. A History of Women in America, New York 1989.

Folly M., Palmer N., Historical Dictionary of U.S. Diplomacy from World War I through World War II, Lanham 2010.

Holmen Mohr L., Frances Perkins. „That Woman in FDR's Cabinet”, Great Barrington 1979.

Jeffreys-Jones R., Changing Differences. Women and the Shaping of American Foreign Policy, 1917-1994, New Brunswick 1995.

Lovoll O.S., The Promise of America. A History of the Norwegian-American People, Minneapolis-London 1999.

Martin G., Madam Secretary. Frances Perkins, New York 1976.

Miller Morin A., Her Excellency. An Oral History of American Women Ambassadors, New York 1995.

Notable American Women. The Modern Period. A Biographical Dictionary, red. B. Sicherman, C. Hurd Green, t. IV, Cambridge 1980.

Olson D.W., Vikings across Atlantic. Emigration and the Building of a Greater Norway, 1860-1945, Minneapolis 2013.

Parafianowicz H., Eleanor Anna Roosevelt. W cieniu wielkiego męża, Warszawa 2000.

Parafianowicz H., O pionierkach $w$ dyplomacji amerykańskiej i Ruth Bryan Owen - pierwszej Madame Poset USA, „Dzieje Najnowsze” 2018, nr 3.

Szelagowska K., Listy z Ameryki. Z dziejów emigracji norweskiej do Stanów Zjednoczonych w XIX wieku, Białystok 2017.

Ware S., Beyond Suffrage. Women in the New Deal, Cambridge 1981.

Weatherford D., American Women during World War II. An Encyclopedia, New York-London 2010.

Wright H., Can a Women Be a Diplomat?, „The North American Review”, Autumn 1939.

Biog r a m: Halina Parafianowicz - prof. zw. dr hab.; pracuje w Instytucie Historii i Nauk Politycznych na Uniwersytecie Białymstoku. Specjalizuje się w dziejach powszechnych, zwłaszcza w społecznej i politycznej historii Stanów Zjednoczonych i Europy Środkowo-Wschodniej w XIX-XX w. Ważnym obszarem jej zainteresowań badawczych są stosunki międzynarodowe, jak również biografistyka (zwłaszcza amerykańscy prezydenci i first ladies) oraz szeroko rozumiana problematyka kobieca, a w szczególności aktywność publiczna i polityczna kobiet. E-mail: halka@uwb.edu.pl. 